\title{
Premature Implanon Discontinuation and Associated Factors Among Implanon User Women in Ambo town, Central Ethiopia,
} 2018

\author{
Kassa Mamo ${ }^{1}$ Melese Siyoum ${ }^{2}$ \\ 1.Department of Midwifery, College of Medicine and Health Sciences, Ambo University, Ambo, Ethiopia \\ 2.Department of Midwifery, College of Medicine and Health Sciences, Hawassa University, Hawassa, Ethiopia
}

\begin{abstract}
Introduction: Contraception have an important role in preventing unwanted and high risk pregnancies, abortions and thereby decreases maternal morbidity and mortality.

Objective: To assess premature discontinuation of Implanon and associated factors among Implanon user women in Ambo town, Central Ethiopia, 2018.

Methodology: Community based cross-sectional study was conducted from May 25 to September 20/2018. A total of 335 women were selected by simple random sampling technique. The collected data were entered using Epi Info ${ }^{\mathrm{TM}}$ version 7 and transferred to statistical software package for social science (SPSS) version 25 for analysis. Binary logistic regression were utilized to get the odds ratio, $95 \%$ confidence interval and $\mathrm{p}$-value to detect statistical association. P-values of $\leq 0.05$ was used to declare significant association and, multiple logistic regression was used to control for confounding.

Result: The overall premature discontinuation of Implanon was 38.2\%. Higher Level of education (AOR $=2.2$, $\mathrm{CI}(1.16,4.16)$, pre insertion counseling $(\mathrm{AOR}=1.2, \mathrm{CI}=(1.02,3.89))$, and experiencing side effects $(\mathrm{AOR}=$ $3.14, \mathrm{CI}=(1.7,5.54))$ were factors significantly associated with premature Implanon discontinuation.

Conclusion and recommendation: Premature discontinuation of Implanon was found to be high in the study area.
\end{abstract}

Keywords: Implanon, premature Discontinuation, Implants, contraception

DOI: $10.7176 / \mathrm{JHMN} / 58-05$

\section{Background}

Contraceptive implants are inserted sub-dermally under the skin in the upper arm. Implanon is a single-rod progestogen-only contraceptive implant with length of $40 \mathrm{~mm}$ and diameter of $2 \mathrm{~mm}$ containing $68 \mathrm{mg}$ of etonogestrel (ENG) dispersed in a membrane of ethylene vinyl acetate. It delivers ENG at a dose sufficient to suppress ovulation in every cycle throughout the 3 years of use [1-3]. Implanon is one of the long-term and reversible sub-dermal contraceptive implants. [4].

Contraceptive discontinuations contribute substantially to the total fertility rate, unwanted pregnancies, and induced abortions $[4,5]$. An estimated $13 \%$ of maternal mortality from unsafe abortion is due to un intended pregnancy[6]. Contraceptive discontinuation in developing countries in the first year of use is common (18 $63 \%$ ), and that the majority of these discontinuations are among women who are still in need of contraception[7].

Implanon is believed to be an effective and safe method; however its discontinuation has been reported to be as much $50 \%$ as high in the developed world [8]. The developing world has low utilization and very high discontinuation due to different reported reasons like changes in menstrual bleeding patterns, mood swings, headaches and weight gain, which could all be addressed during service provision through counselling $[9,10$, $11,12]$.

Despite the development of a plan to expand contraception by providing at the community level since 2009 by the Federal Ministry of Health of Ethiopia (FMoH), utilization of long acting family planning method (LAFP) is low and high number of premature discontinuations were reported[13-16]. Since risk factors are varied across settings, the current study was designed to identify factors associated with premature discontinuation of Implanon in Ambo town, Central Ethiopia.

\section{METHODOLOGY}

\section{Study setting}

Community based cross sectional study was conducted in Ambo town, Central Ethiopia, from May 2015 to September 2018. The town found $112 \mathrm{Km}$ away to the west of the capital Addis Ababa and it is the capital city of West Shoa Zone. According to the 2007 national census reported the total population of Ambo town was 48,171, of whom 24,634 were men and 23,537 were women. The city has one referral hospital, one general hospital and two health centers [33]. 


\section{Source population}

All women who are Implanon users in Ambo Town.

\section{Study Population}

All women to whom Implanon was inserted two and half years prior to the data collection period in Ambo town are the study population.

\section{Sample size determination}

Sample size was determined using single population proportion formula considering over all discontinuation rate of $16 \%$ (5), and non-response rate of $10 \%$ at $95 \%$ confidence level and marginal error of $4 \%$, and the required minimum sample size is 356 .

\section{Sampling procedures}

Women for whom Implanon was inserted in the last three years, three years were identified first from the family planning registration book obtained from health extension workers of the city. Then the list of users name were assigned a code for each and 356 participants were selected using simple random sampling technique.

\section{Operational definition \\ Premature Implanon discontinuation: removal of Implanon before two and half years Data collection tools and procedures}

Data were collected using a face to face interview using structured questionnaire adapted from references. The questionnaire was first prepared in English and translated to Afan Oromo (local language). Six data collectors who are midwives by profession and two supervisors who are Master of Science holders were participated in the study.

\section{Data quality control}

The Questionnaires were prepared in English and translated to local language (Afan Oromo). The questionnaires were pretested using 5\% (18) of the study participants two weeks ahead of the actual study period. By doing so, the reaction of the respondents to the research procedure, the need of revising the format or presentation of the questionnaire, the successfulness of data collectors' training, appropriateness of the amount of time allowed for different activities and generally inconsistent and confusing matters were evaluated and corrected accordingly. The completeness of the questionnaire was checked by supervisor daily and the principal investigator also rechecked it for its completeness before data entry.

\section{Data processing and analysis}

The univariate analysis such as proportions, percentages, frequency distributions and appropriate graphic presentations besides measures of central tendency and measures of dispersion were used for data presentation. Data collected were analyzed using SPSS version 25 statistical software. Binary logistic regression were utilized to get the odds ratio, 95\% confidence interval and p-value to detect statistical association. P-values of $\leq 0.05$ was used to declare significant association and, multiple logistic regression was used to control for confounding.

\section{Ethical clearance}

Ethical approval was obtained from the Ethical Committee of Ambo University Research and Publication Office. The purpose and importance of the research was explained to each of the study participants and the data was collected after a full informed verbal consent was obtained.

\section{RESULTS}

Socio demographic characters of the study participants

Three hundred thirty five $(n=335)$ participants had responded to the questionnaire making a response rate of $94.1 \%$. Their ages lie in the age range of 18 and 46 years with the mean $( \pm$ SD) age of $27.97 \pm 5.45$ years. Majority of the study participants $(71.8 \%)$ identified themselves as Oromo for ethnicity. A little more than half of the study participants $(52.2 \%)$ were Orthodox Christianity followers followed by Protestantism. The average monthly income ranges from 00.00 (no constant income) to 9900 ETB with a median of 1600.00 ETB (Table 1). 


\begin{tabular}{|c|c|c|c|}
\hline & & Number & Percent \\
\hline \multirow[t]{6}{*}{ Participant's Age } & $\leq 20$ & 35 & 10.5 \\
\hline & $\overline{2} 1-25$ & 80 & 23.9 \\
\hline & $26-30$ & 120 & 35.8 \\
\hline & $31-34$ & 58 & 17.3 \\
\hline & $>35$ & 42 & 12.5 \\
\hline & Oromo & 241 & 71.8 \\
\hline \multirow[t]{4}{*}{ Women's Ethnicity } & Amhara & 55 & 16.4 \\
\hline & Gurage & 23 & 6.8 \\
\hline & Others & 17 & 5.0 \\
\hline & Orthodox & 175 & 52.2 \\
\hline \multirow[t]{3}{*}{ Women's Religion } & Protestant & 138 & 41.2 \\
\hline & Muslim & 22 & 6.6 \\
\hline & Single & 48 & 13.3 \\
\hline \multirow[t]{3}{*}{ Marital status } & Married & 243 & 72.5 \\
\hline & Divorced & 44 & 13.1 \\
\hline & Gov't Employee & 94 & 28.1 \\
\hline \multirow[t]{6}{*}{ Occupation } & House wife & 86 & 25.7 \\
\hline & Merchant & 46 & 13.7 \\
\hline & Private Employee & 45 & 13.4 \\
\hline & Daily laborer & 42 & 12.5 \\
\hline & Others & 22 & 6.6 \\
\hline & $<750$ & 82 & 24.5 \\
\hline Average & $751-1600$ & 91 & 27.2 \\
\hline \multirow{2}{*}{ Income } & $1601-3000$ & 98 & 29.2 \\
\hline & $>3000$ & 64 & 19.1 \\
\hline \multirow{4}{*}{$\begin{array}{l}\text { Women's } \\
\text { education }\end{array}$} & Non formal education & 97 & 28.9 \\
\hline & Primary school & 74 & 22.1 \\
\hline & Secondary school & 84 & 25.1 \\
\hline & Above Secondary school & 80 & 23.9 \\
\hline Total & & 335 & 100 \\
\hline
\end{tabular}

Table 1: Socio demographic Status of women who used Implanon in the last three years in Ambo town, 2018.

\section{Reproductive and past contraceptive history}

Majority $245(73.1 \%)$ of the participants have history of pregnancy at least once before they use implanon. Among them 231(94.3\%) has at least one alive child. Majority of the participants $260(77.6 \%)$ have a desire to be pregnant in the future (Table 2).

Character

Ever get pregnant

Have alive children $(\mathrm{n}=245)$

History of abortion $(\mathrm{n}=245)$

Need to get pregnant

When did you plan for pregnancy $(n=260)$

$\begin{array}{lll} & \text { Number } & \text { Percent } \\ \text { Yes } & 245 & 73.1 \\ \text { No } & 90 & 26.9 \\ \text { Yes } & 231 & 94.3 \\ \text { No } & 14 & 5.7 \\ \text { Yes } & 47 & 19.2 \\ \text { No } & 198 & 80.8 \\ \text { Yes } & 260 & 77.6 \\ \text { No } & 75 & 22.4 \\ \text { From now on } & 57 & 21.9 \\ \text { After 1 year } & 43 & 16.5 \\ \text { After 2 years } & 54 & 20.8 \\ \text { After 3 years } & 106 & 40.8\end{array}$

Table 2: Implanon discontinuation among women who ever used Implanon in Ambo town, 2018.

\section{Pre insertion counseling service during Implanon provision}

Majority of the participants claimed that they have got counselling service from their providers 256 (76.4\%), from which most of them have received an individual counselling 228 (89.1\%). The most common topics of counselling were advantage and duration of action of Implanon, where $229(89.4 \%)$ and $226(88.3 \%)$ has reported that they have been counseled on. $116(34.6 \%)$ women reported that they were not satisfied with the service provided [Table 3] 


\begin{tabular}{|c|c|c|c|}
\hline Character & Response & Number & Percen \\
\hline \multirow[t]{2}{*}{ Got counseling service $(n=335)$} & Yes & 256 & 76.4 \\
\hline & No & 79 & 23.4 \\
\hline \multirow[t]{2}{*}{ Type of counseling $(n=256)$} & Individual & 228 & 89.1 \\
\hline & Group counseling & 28 & 10.9 \\
\hline \multirow{5}{*}{ Topics discussed during counseling $(n=256)$} & Advantage of Implanon & 229 & 89.4 \\
\hline & Duration of action of" & 226 & 88.3 \\
\hline & Effectiveness of" & 186 & 72.6 \\
\hline & Side effect of $"$ & 174 & 67.9 \\
\hline & Bleeding disorder & 151 & 81.2 \\
\hline \multirow[t]{3}{*}{ Possible side effects counseled $(n=174)$} & Headache & 107 & 57.5 \\
\hline & Weight gain & 75 & 40.3 \\
\hline & Myself & 189 & 56.4 \\
\hline \multirow[t]{3}{*}{ Main decider to use the method $(n=335)$} & Discussion with husband & 69 & 20.6 \\
\hline & Method provider & 61 & 18.2 \\
\hline & My husband & 16 & 4.8 \\
\hline \multirow[t]{3}{*}{ Reason for choosing the method $(n=335)$} & Duration of action & 249 & 74.3 \\
\hline & Effectiveness & 47 & 14.1 \\
\hline & No side effect & 39 & 11.6 \\
\hline \multirow{7}{*}{$\begin{array}{l}\text { Perceived Satisfaction with service provided } \\
(\mathrm{n}=335) \\
\text { Site of Implanon provision }\end{array}$} & Yes & 219 & 65.4 \\
\hline & No & 116 & 34.6 \\
\hline & Health center & 180 & 53.7 \\
\hline & Hospital & 60 & 18.1 \\
\hline & Marie stops & 45 & 13.5 \\
\hline & FGAE & 41 & 12.1 \\
\hline & Private clinics & 9 & 2.6 \\
\hline
\end{tabular}

The most commonly reported reasons for discontinuation were presence of side effect $96(62 \%)$ need to get pregnant 46 (29.7\%), spouse death 7, husband disapproval 4, and failed method two (Figure 1).

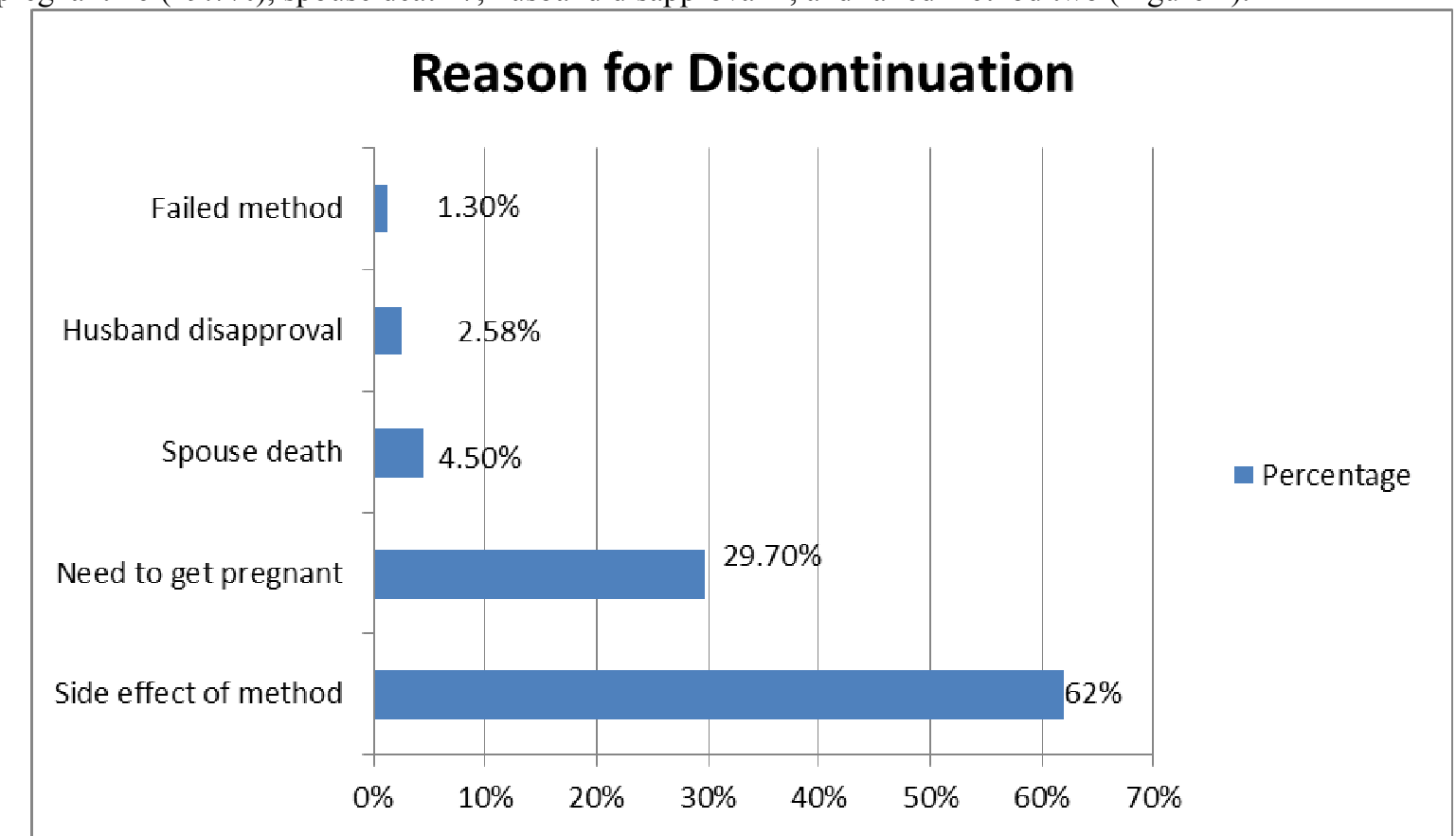

Figure 1: Reasons for discontinuation of Implanon among women who ever used the method in Ambo town, 2018

Most commonly reported side effects causing Implanon discontinuations were menstrual disturbance 58(60.4\%), and Arm pain 22(22.9\%). Nine participants out of 12, who developed mood change, had already discontinued the method (Figure 2). Among participants who did not discontinued the method (180) during study period, $37(20.5 \%)$ of them decided to discontinue before completion of three years due to discomfort $28(75.6 \%)$ and need to be pregnant is reported by six participants. 


\section{Specific side effects causing Discontinuation}

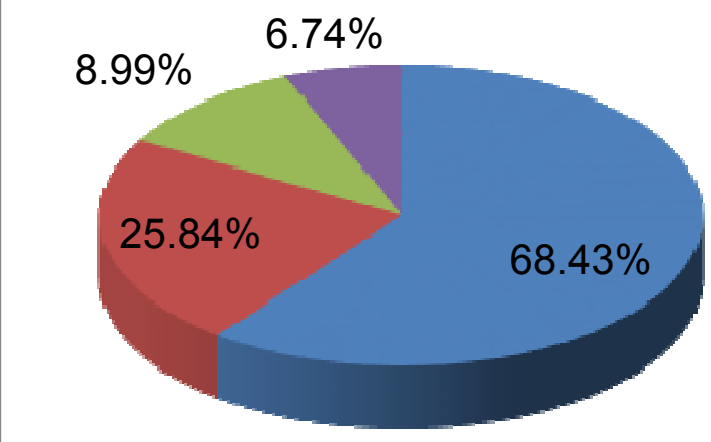

Menstrual disturbance

Arm pain

Weight gain

- Headache

Figure 2: Specific Side effects causing Implanon Discontinuation among women who ever used implanon in the last three years in Ambo Town, Central Ethiopia, 2018.

\section{Factors Associated with Premature Discontinuation of Implanon}

Variables like women's ethnicity, information about contraceptive prior to Implanon use, Implanon provision site, checkup appointment, main decision maker to use the method and mood change were excluded from analysis for association due to low frequencies in one category when checked by cross tabulation. All other socio demographic characters, reproductive and obstetric factors, counseling service and method choice, and experience of side effect were checked individually for the presence of association in binary logistic regression and women's age, level of education, history of pregnancy, pre insertion counseling service, reason for preferring method, history of contraceptive use, and presence of side effect were significantly associated with Implanon discontinuation. However, in multiple logistic regression only variables like level of education above secondary school, pre insertion counseling service and experience of side effect were significantly associated with premature Implanon discontinuation. The result showed that the odds of discontinuation among women who had completed secondary school were more than 2 times higher than the odds in those who have no formal education $(\mathrm{AOR}=\mathbf{2 . 2}, 95 \% \mathrm{CI}=\mathbf{( 1 . 1 6 - 4 . 1 6}) \mathrm{P}=0 \mathbf{0 . 0 4 6})$. The odds of discontinuation in women who were not counseled on possible side effect of the method were 1.2 times higher than odds in those who were counseled on side effects $(\mathrm{AOR}=\mathbf{1 . 2}, 95 \% \mathrm{CI}=(\mathbf{1 . 0 2}-\mathbf{3 . 8 9}), \mathrm{p}=0.002)$. The odds of Implanon discontinuation among women who ever faced side effect of the method were 3.14 times higher than odds in women who did not face side effects $(A O R=3.14,95 \%$ CI $=(\mathbf{1 . 7 - 5 . 5 4}), p=0.034)$ [Table 4]. 


\begin{tabular}{|c|c|c|c|c|c|c|}
\hline \multirow[t]{2}{*}{ Variable } & & \multicolumn{2}{|c|}{ Implanon discontinued } & \multirow{2}{*}{$\begin{array}{l}\text { Crude OR } \\
(95 \% \text { CI) }\end{array}$} & \multirow{2}{*}{$\begin{array}{l}\text { Adjusted OR } \\
(95 \% \text { CI })\end{array}$} & \multirow{2}{*}{$\begin{array}{l}P \text { - } \\
\text { value }\end{array}$} \\
\hline & & Yes $(\%)$ & No $(\%)$ & & & \\
\hline Women's & $>35$ & 24() & 18() & $0.48(0.22-1.48)$ & & \\
\hline \multirow{4}{*}{ Age } & $31-35$ & 19 & 39 & $0.22(0.07-0.42)$ & $*$ & \\
\hline & $26-30$ & 48 & 72 & $0.30(0.16-0.76)$ & $*$ & \\
\hline & $21-25$ & 40 & 40 & $0.45(0.25-1.28)$ & & \\
\hline & $<21$ & 24 & 11 & 1 & 1 & \\
\hline \multirow[t]{4}{*}{$\begin{array}{l}\text { Level of } \\
\text { education }\end{array}$} & $\begin{array}{l}\text { Above } \\
\text { secondary } \\
\text { school }\end{array}$ & 49 & 31 & $2.06(1.21-3.62)$ & $2.2(1.16-4.16)$ & 0.016 \\
\hline & 2 dry school & 38 & 46 & $1.08(0.5-1.82)$ & $*$ & \\
\hline & $\begin{array}{l}\text { Primary } \\
\text { school }\end{array}$ & 26 & 48 & $0.7(0.41-1.68)$ & $*$ & \\
\hline & $\begin{array}{l}\text { No formal } \\
\text { education }\end{array}$ & 42 & 55 & 1 & 1 & \\
\hline Got & No & 55 & 24 & $3.57(1.9-6.1)$ & $1.2(1.02-3.89)$ & 0.044 \\
\hline $\begin{array}{l}\text { counselling } \\
\text { service }\end{array}$ & Yes & 100 & 156 & 1 & 1 & \\
\hline \multirow{3}{*}{$\begin{array}{l}\text { Reason for } \\
\text { choosing } \\
\text { method }\end{array}$} & Effectiveness & 28 & 19 & $2.15(1-3.6)$ & $*$ & \\
\hline & $\begin{array}{l}\text { No side } \\
\text { effect }\end{array}$ & 26 & 13 & $2.93(1.46-5.83)$ & $*$ & \\
\hline & Long term & 101 & 148 & 1 & & \\
\hline Ever faced & Yes & 122 & 103 & $2.3(1.69-4.59)$ & $3.14(1.7-5.54)$ & $<0.001$ \\
\hline side effects & No & 37 & 73 & 1 & 1 & \\
\hline
\end{tabular}

Table 4: Factors Associated with Discontinuation of Implanon among women who used Implanon in Ambo town, 2018.

\section{DISCUSSIONS}

The overall premature discontinuation of implanon was $46.3 \%$ with median duration of use 12 months. This goes consistently with study conducted in Australia where $47 \%$ of women using implant has discontinued within three years [17]; however this study has shown that there is a high premature discontinuation compared to studies conducted in Nigeria, Egypt and Malaysia where discontinuation was 26.1\%, 28\% and 22.86\% respectively [9, $18,19]$. The differences might stem from variations in study area, time of the study, sample size differences and also service provision approaches would have played their roles.

Incoherent to other studies in home [16, 29] and abroad $[6,7,18,27]$ and our exppectations, the study found that women who have completed secondary school were two times more likely to prematurely discontinue implanon compared to those who have no formal education $[\mathrm{AOR}=2.2,95 \% \mathrm{CI}=1.16,4.16)]$. This might explain the fact that early healthcare seeking is common when there is any disturbance from normal physiology among women who are more educated compared to women who are not. Moreover educational status of study participants may have contributed for the variability, in which; studies in the country has included more of participants with no formal education and others studies have included women with formal education.

The odds of Implanon discontinuation among women who were not counseled prior to insertion of implanon were 1.2 times higher than the odds in those who were counseled (AOR $=1.2,95 \% \mathrm{CI}=1.02,3.89$, $\mathrm{p}=0.044$ ). This might be due to the fact that women who are informed well on possible side effect of the method will tolerate side effects but those who were not informed will seek removal of the method. Timely follow up and appropriate counseling helps the women to cope with side effects which ultimately prevents discontinuation.

In this study experiencing side effects was significantly associated with premature discontinuation of implanon, where women who had experienced method related side effects were 3 times (AOR $=3.14,95 \% \mathrm{CI}$ $=1.7,5.54, \mathrm{p}<0.001)$ more likely to discontinue compared to women who hadn't experienced side effect which is in line with a study conducted in Tigray, Northern Ethiopia (16). This might be due to women's intolerance for minor side effects, particularly with no or inappropriate counselling. Unexpected changes in menstrual bleeding due to the nature of the the method by itself rarely may force women to seek for removal.

\section{Conclusion}

In this study discontinuation of Implanon was high. Women's Age, Level of education, counselling service, experience of side effects were factors associated with discontinuation. Quality family planning service which incorporates thorough counseling on side effects is fundamental to minimize premature discontinuation. 


\section{Limitations}

There may be recall bias as some questions asks information on before three years. Moreover, severity of side effects was not diagnosed.

\section{Competing interests}

The authors declared that they have no competing interests.

\section{Author's contribution}

MS conceived the study and was involved in the study design, reviewed the article, analysis, report writing and drafted the manuscript. KM was involved in the study design, analysis and drafted the manuscript. The authors read and approved the final manuscript.

\section{Acknowledgement}

The authors acknowledge Ambo University for the financial and material support. The authors appreciate study participants \& data collectors for their cooperation in providing all necessary information.

\section{REFERENCES}

1. Royal College of Obstetrician and Gynecologists; Long-acting reversible contraception, the effective and appropriate use of long-acting reversible contraception 2005.

2. Mascarenhas L. Insertion and removal of Implanon ${ }^{\circledR}$. Contraception. 1998. doi:10.1016/S00107824(98)00121-8.

3. Curtis KM, Jatlaoui TC, Tepper NK, et al. U.S. Selected Practice Recommendations for Contraceptive Use, 2016. MMWR Recomm Reports. 2016. doi:10.15585/mmwr.rr6504a1

4. Mutihir JT, Nyango DD. Indications for removal of etonogestrel implant within two years of use in Jos, Nigeria. East Afr Med J. 2010 Nov;87(11)461-4. PubMed PMID: 23457809. Epub 2010/11/01. eng.

5. Henry N, Schlueter M, Lowin J, Lekander I, Filonenko A, Trussell J, et al. Cost of unintended pregnancy in Norway: a role for long-acting reversible contraception. J Fam Plann Reprod Health Care. 2014 Dec 23. PubMed PMID: 25537792. Epub 2014/12/30. Eng.

6. Tsui AO, McDonald-Mosley R, Burke AE. Family planning and the burden of unintended pregnancies. Epidemiol Rev. 2010 Apr;32(1):152-74. PubMed PMID: 20570955. Pubmed Central PMCID: PMC3115338. Epub 2010/06/24. eng.

7. Bongaarts J, Cleland J, Townsend JW, Bertrand JT. Family planning programs for the 21 st century: Rationale and design. 2012.

8. Harvey C, Seib C, Lucke J. Continuation rates and reasons for removal among Implanon users accessing two family planning clinics in Queensland, Australia. Contraception. 2009 Dec;80(6):527-32. PubMed PMID: 19913146. Epub 2009/11/17. eng.

9. Balogun O, Olaomo N, Adeniran A, Fawole A. Implanon sub-dermal implant: an emerging method of contraception in Ilorin, Nigeria. Journal of Medical and Biomedical Sciences. 2014;3(1):1-5.

10. Mutihir J, Nyango D. One-year experience with implanon sub-dermal implants in Jos, Nigeria. Nigerian Journal of Clinical Practice. 2010;13(1).

11. Ireland LD, Goyal V, Raker CA, Murray A, Allen RH. The effect of immediate postpartum compared to delayed postpartum and interval etonogestrel contraceptive implant insertion on removal rates for bleeding. Contraception. 2014 Sep;90(3):253-8. PubMed PMID: 24973904. Epub 2014/06/30. eng.

12. Hoggart L, Newton V, Dickson J. Full Report. Understanding long-acting reversible contraception: an indepth investigation into sub-dermal contraceptive implant removal amongst young women in London. A report for the London Sexual Health Commissioning Programme. 2013.

13. Asnake M, Solter C, Tilahun Y, Vespia M. Strengthening health systems to ensure equitable access to implant removal services in Ethiopia. 2013.

14. Asnake M, Tilahun Y. Scaling up community-based service delivery of Implanon: the Integrated Family Health Programâ s experience training health extension workers. 2010.

15. Asnake M, Henry EG, Tilahun Y, Oliveras E. Addressing unmet need for long-acting family planning in Ethiopia: uptake of single-rod progestogen contraceptive implants (Implanon) and characteristics of users. Int J Gynaecol Obstet. 2013 Nov;123 Suppl 1:e29-32. PubMed PMID: 24035007. Epub 2013/09/17. eng.

16. KALAYU B. EARLY DISCONTINUATION RATE OF IMPLANON AND ITS ASSOCIATED FACTORS AMONG WOMEN WHO EVER USED IMPLANON IN 2012/2013 IN OFLA WOREDA, TIGRAY, NORTHERN ETHIOPIA, 2014: AAU; 2014.

17. Weisberg E, Bateson D, McGeechan K, Mohapatra L. A three-year comparative study of continuation rates, bleeding patterns and satisfaction in Australian women using a subdermal contraceptive implant or progestogen releasing-intrauterine system. The European Journal of Contraception \& Reproductive Health Care. 2014;19(1):5-14.

18. Mastor A, Khaing SL, Omar SZ. Users' perspectives on Implanon in Malaysia, a multicultural Asian 
country. Open Access Journal of Contraception. 2011:79-84.

19. Said MA-RM, Cairo U. Implanon Use Pattern among Ministry of Health and Population Clients 20082012.Faculty of Medicine,Cairo 2012 December,2012.

20. Eva G, Ngo TD. MSI Mobile Outreach Services: Retrospective evaluations from Ethiopia, Myanmar, Pakistan, Sierra Leone and VietNam. London: Marie Stopes International. 2010.

21. Hardee K, Harris S, Rodriguez M, Kumar J, Bakamjian L, Newman K, et al. Achieving the Goal of the London Summit on Family Planning By Adhering to Voluntary, Rights-Based Family Planning: What Can We Learn from Past Experiences with Coercion?

22. Madden T, Eisenberg DL, Zhao Q, Buckel C, Secura GM, Peipert JF. Continuation of the etonogestrel implant in women undergoing immediate postabortion placement. Obstet Gynecol. 2012 Nov;120(5):10539. PubMed PMID: 23090522. Pubmed Central PMCID: PMC3711380. Epub 2012/10/24. eng.

23. Rosenstock JR, Peipert JF, Madden T, Zhao Q, Secura GM. Continuation of reversible contraception in teenagers and young women. Obstet Gynecol. 2012 Dec;120(6):1298-305. PubMed PMID: 23168753. Pubmed Central PMCID: PMC4037699. Epub 2012/11/22. eng.

24. Jacobstein R, Polis CB. Progestin-only contraception: injectables and implants. Best Pract Res Clin Obstet Gynaecol. 2014 Aug;28(6):795-806. PubMed PMID: 24996766. Epub 2014/07/06. eng.

25. Duvan Cİ, Gözdemir E, Kaygusuz İ, Kamalak Z, Turhan NÖ. Etonogestrel contraceptive implant (Implanon): Analysis of patient compliance and adverse effects in the breastfeeding period. Journal of the Turkish German Gynecological Association. 2010;11(3):141.

26. O'Neil-Callahan M, Peipert JF, Zhao Q, Madden T, Secura G. Twenty-four-month continuation of reversible contraception. Obstet Gynecol. 2013 Nov;122(5):1083-91. PubMed PMID: 24104781. Pubmed Central PMCID: PMC4012225. Epub 2013/10/10. eng.

27. Peipert JF, Zhao Q, Allsworth JE, Petrosky E, Madden T, Eisenberg D, et al. Continuation and satisfaction of reversible contraception. Obstet Gynecol. 2011 May;117(5):1105-13. PubMed PMID: 21508749. Pubmed Central PMCID: PMC3548669. Epub 2011/04/22. eng.

28. Grunloh DS, Casner T, Secura GM, Peipert JF, Madden T. Characteristics associated with discontinuation of long-acting reversible contraception within the first 6 months of use. Obstet Gynecol. 2013 Dec;122(6):1214-21. PubMed PMID: 24201685. Pubmed Central PMCID: PMC4051392. Epub 2013/11/10. eng.

29. Burusie A. Reasons for Premature Removal of Implanon among Users in Arsi Zone, Oromia Region, Ethiopia, 2013. Reproductive System \& Sexual Disorders. 2015;2015.

30. Halpern V, Lopez LM, Grimes DA, Stockton LL, Gallo MF. Strategies to improve adherence and acceptability of hormonal methods of contraception. status and date: New search for studies and content updated (no change to conclusions), published in. 2013 (10).

31. Wellisch LD, Chor J. LARC First: What the General Pediatrician Needs to Know about IUDs and Contraceptive Implants. Pediatric annals. 2013;42(9):380-3.

32. Rowlands S, Searle S, Rowlands S, Searle S. Contraceptive implants: current perspectives. Clinical, Cosmetic and Investigational Dentistry. 2014;6:45-56.

33. CSA (Central Statistic Agency). Population and housing census of Ethiopia. Cent Stat agency. 2007. doi:10.1007/s13398-014-0173-7.2

34. Mengstu Melkamu Asaye et al. "Early Implanon Discontinuation and Associated Factors among Implanon User Women in Debre Tabor Town, Public Health Facilities, Northwest Ethiopia, 2016," International Journal of Reproductive Medicine, vol. 2018, Article ID 3597487, 10 pages, 2018. https://doi.org/10.1155/2018/3597487. 